\title{
Sweet sorghum and its bagasse ensiled with urea and molasses can be used as alternatives for maize silage in semi-arid areas from in situ and gas production evaluations
}

\author{
Shahabodin Zafari Naeini ${ }^{1}$, Ebrahim Rowghani ${ }^{* 2}$, Nima Khodambashi Emami ${ }^{3}$, Ali-Reza Bayat ${ }^{4}$ and \\ Ebrahim Abolfathi ${ }^{2}$ \\ ${ }^{1}$ Department of Animal Science, College of Agriculture, Shiraz University, Shiraz, Iran \\ ${ }^{2}$ Department of Animal Science, College of Agriculture, Darab Branch, Islamic Azad University, Darab, Iran \\ ${ }^{3}$ Department of Animal Science, College of Agriculture, Ferdowsi University of Mashhad, Mashhad, Iran \\ ${ }^{4}$ Nutritional Physiology, Green Technology, Natural Resources Institute Finland (Luke), Jokioinen, FI-31600,
}

Finland

\section{Article history}

Received: 5 Oct, 2016

Revised: 23 Oct, 2016

Accepted: 24 Oct, 2016

\begin{abstract}
In situ degradability and gas production (GP) parameters of sweet sorghum and sweet sorghum bagasse silages compared with maize silage were determined in mini silos in order to compare the nutritional value of ensiled sweet sorghum and its bagasse with maize silage. Experimental treatments were 1) maize silages (MS) as control, 2) sweet sorghum silage (SS) and 3) sweet sorghum bagasse silage (BS) both supplemented with urea or molasses (10 and $50 \mathrm{~g} / \mathrm{kg}$ dry matter (DM) basis, respectively). Triplicate silage samples were prepared for each treatment in laboratory silos for 90 days. The in situ degradability of DM and crude protein (CP) of fresh and 90-d ensiled forages were measured using three none lactating dairy cows fitted with rumen cannulae over $96 \mathrm{~h}$. In vitro gas production was measured for $96 \mathrm{~h}$ and organic matter digestibility (OMD), metabolisable energy $(\mathrm{ME})$ and net energy for lactation $\left(\mathrm{NE}_{\mathrm{l}}\right)$ were estimated based on gas production parameters. Fresh sorghum and its bagasse had lower $(\mathrm{P}<0.01) \mathrm{ME}$, $\mathrm{NEl}$ and OMD than fresh maize. Fresh sorghum and bagasse had greater $(\mathrm{P}<0.05)$ immediately soluble fraction $(a)$ of DM than fresh maize but for slowly degradable fraction $(b)$ of $\mathrm{DM}$ opposite trend $(\mathrm{P}<0.01)$ was observed. The $a$ fraction of $\mathrm{CP}$ in situ degradability of maize plant was greater than fresh sorghum and bagasse $(\mathrm{P}<0.01)$. Adding urea plus molasses increased $(\mathrm{P}<0.05)$ in situ a fraction of $\mathrm{DM}$ and $\mathrm{CP}$ and effective rumen degradability of $\mathrm{DM}$ and $\mathrm{CP}(\mathrm{P}<0.01)$ in addition to $\mathrm{ME}$ and in vitro OMD for SS and BS which were rather comparable with MS. It seems that combination of urea and molasses as silage additives improves the nutritional quality of sweet sorghum and bagasse silages.

Keywords: Maize, sweet sorghum, sweet sorghum bagasse, silage, in situ degradability, gas production
\end{abstract}

To cite this article: Naeini SZ, E Rowghani, NK Emami, AR Bayat, E Abolfathi, 2016. Sweet sorghum and its bagasse ensiled with urea and molasses can be used as alternatives for maize silage in semi-arid areas from in situ and gas production evaluations. Res. Opin. Anim. Vet. Sci., 6(8): 248-255.

*Corresponding author: Ebrahim Rowghani, Department of Animal Science, College of Agriculture, Darab Branch, Islamic Azad University, Darab, Iran; Email: erowghani@yahoo.com 


\section{Introduction}

Maize (Zea mays L.) silage is used extensively for lactating dairy cows. However, maize requires large quantity of water (Gowda et al., 2007) in order to be high yielding and have good nutritional quality. One way to continue forage production under declining water resources is to replace maize with alternative crops which are more efficient in using water. Sweet sorghum (Sorghum bicolor var. saccharatum) is a crop that provides grain and stem that can be used for sugar, alcohol, syrup, fodder, fuel, bedding, roofing, fencing, paper and chewing. Sorghum due to good adaptation to harsh environmental conditions, high water useefficiency and high production, even in low water conditions, is an important forage crop in many parts of the world (Almodares et al., 2008). It is often grown in areas of low fertility and unpredictable rainfall (VanOosteroma et al., 2001). Sweet sorghum usually is planted for sugar (Almodares and Sepahi, 1996) and ethanol production (Sipos et al., 2009). Sorghum is cultivated in 7.84 and 0.137 million ha in the Asia and Europe, respectively (FAO, 2013).

A previous study has shown that lactating dairy cows fed normal forage sorghum had less intake and produced less milk than cows fed traditional forages such as maize and alfalfa silages (Oliver et al., 2004). Reductions in dry matter (DM) intake and milk yield ranged from 11.7 to $15 \%$ and from 8.3 to $27.1 \%$, respectively (Amer et al., 2012). Historically, sorghum silage energy content and digestibility have been lower than that of maize (NRC, 2001). Some attempts have been made to increase nutritive value of sorghum silage. Harris and Mitchell (1941) introduced urea as the best nitrogen source that has not any toxicity effects in cattle and sheep. Urea can be used for increasing nitrogen concentration and improving the fermentation quality of sorghum forage (Filya, 2001). Also molasses can be used as a water-soluble carbohydrates (WSC) source for fast fermentation and lactic acid production by lactic acid bacteria and increasing dry matter content (McDonald et al., 1991).

The beneficial effects of adding urea and molasses to sorghum silages have been reported (Demirel et al., 2004; Guney et al., 2007). Urea-treated feeds increase the rumen fluid $\mathrm{pH}$ and fiber digestibility, and consequently increase the silage consumption (Tetlow, 1992). Cabral Filho et al. (2005) have reported that sorghum has high apparent DM degradation $(600 \mathrm{~g} / \mathrm{kg})$. However, there are opposite findings about sorghum nutritional characteristics, which could be due to differences in hybrid or variety (Bolsen et al., 2003; Oliver et al., 2004). The DM digestibility in sorghum silage with grain is more than forage sorghum silage, which is due to the greater digestion of grain (Pesce et al., 2000; Bolsen et al., 2003).
The objective of the current study was to evaluate the nutritional quality of sweet sorghum and sweet sorghum bagasse silages ensiled with or without urea and molasses under laboratory conditions compared to maize silage as determined by in situ degradability and gas production techniques.

\section{Materials and Methods}

\section{Plant materials}

Sweet sorghum (Sorghum bicolor var. saccharatum) and maize were planted on 5 and 22 June 2014 and harvested after 120 days and 70 days (early dent), respectively in Isfahan University Research Station ( $32^{\circ} 34^{\prime} \mathrm{N}, 51^{\circ} 45^{\prime} \mathrm{E}$, altitude $\left.1550 \mathrm{~m}\right)$. The plant materials are described in details by Zafari Naeini et al. (2014). To obtain the sorghum bagasse, the grain clusters and leaves were separated from the stem. The resulted stems were extracted using an apparatus having two pairs of rollers to reduce the weight by $200 \pm 20$ $\mathrm{g} / \mathrm{kg}$ fresh weight. Extracted stems along with separated leaves were chopped into $2-3 \mathrm{~cm}$ pieces. Whole plant maize and sweet sorghum forages including stems, seeds and leaves were chopped similarly.

\section{Ensiling procedure and treatments}

Whole sorghum and maize plants and sorghum bagasse were ensiled in PVC containers $(12 \times 60 \mathrm{~cm}$; $4.0 \pm 0.2 \mathrm{~kg}$ capacity) with the density of $521 \pm 62.5$, $543 \pm 48.5$ and $451 \pm 29.0 \mathrm{~kg} / \mathrm{m}^{3}$ for maize, sweet sorghum and sorghum bagasse, respectively. Urea and molasses (10 and $50 \mathrm{~g} / \mathrm{kg}$ on DM basis, respectively) were added to the silage batches prior to filling whenever appropriate. The ensiling procedure is described by Zafari Naeini et al. (2014). The laboratory silos were placed in a dark room with average temperature of $18^{\circ} \mathrm{C}$ until their opening at 90 days later.

The experimental treatments were as following: 1) maize silage (MS), 2) sweet sorghum silage (SS), 3) sweet sorghum silage plus urea (SSU), 4) sweet sorghum silage plus urea and molasses (SSUM), 5) sweet sorghum bagasse silage (BS), 6) sweet sorghum bagasse silage plus urea (BSU), 7) sweet sorghum bagasse silage plus urea and molasses (BSUM). Each treatment had three replicates.

\section{Sampling and chemical analysis of fresh and ensiled forages}

After chopping, $500 \mathrm{~g}$ of fresh forage was dried at $55^{\circ} \mathrm{C}$ for $48 \mathrm{~h}$ in triplicate and ground to pass a $1 \mathrm{~mm}$ screen for chemical analysis and in vitro degradability. Fermentation characteristics were measured as described previously by Zafari Naeini et al. (2014). The silages were evaluated after 90 days of ensiling. 


\section{In situ rumen degradability of DM and CP}

The in situ measurements of ruminal DM and CP degradations were carried out using three non-lactating Holstein cows (third parity and above; $740 \pm 11.2 \mathrm{~kg}$ live weight) equipped with ruminal cannulae. The cows were housed in an air-conditioned room with maximum and minimum temperature of $25.0 \pm 2.5$ and $17.0 \pm 1.8^{\circ} \mathrm{C}$, respectively. A maintenance ration (AFRC, 1992) was fed in equal portions two times per day (07:00 and 19:00) consisting of approximately $490 \mathrm{~g} / \mathrm{kg}$ silage (1:1 MS:SS), $400 \mathrm{~g} / \mathrm{kg}$ chopped alfalfa, $100 \mathrm{~g} / \mathrm{kg}$ concentrate (containing $5 \mathrm{~g} / \mathrm{kg}$ urea) and $10 \mathrm{~g} / \mathrm{kg}$ molasses. Also an adaptation period of 10 days was allowed before incubations. Three $\mathrm{g}$ dry samples ground with $2 \mathrm{~mm}$ sieve, transferred into polyester bags (pore size, $52 \pm 10 \mu \mathrm{m}$; internal dimensions, $10 \times 15 \mathrm{~cm}$ ). Bags were placed sequentially in the ventral rumen of the three fistulated cows in duplicate, whereas the third bag served as blank. Samples were soaked in water for 3 min before ruminal incubation for 2, 4, 8, 12, 24, 48, 72 , and $96 \mathrm{~h}$ in a mesh bag. Also, six bags (three cows $\times$ two replicates) were washed with cold tap water to estimate zero time incubation. Upon removal of the bags (including the zero time incubation), samples were hand-washed with cold water 5 times for 4 min each until the rinse water remained clear and then dried at $55^{\circ} \mathrm{C}$ for $48 \mathrm{~h}$. After drying, bags were weighed and rate of disappearance and lag time were calculated with non-linear regression (Ørskov and McDonald, 1979) using the NLIN procedure of SAS (2003) as below:

\section{$\mathrm{P}=\mathrm{a}+\mathrm{b}\left(1-\mathrm{e}^{\mathrm{ct}}\right)$}

where, $\mathrm{P}$ is the proportion of disappeared material at time $\mathrm{t}, a$ is immediately disappeared fraction, $b$ is slowly degradable fraction which disappears at a measurable rate and $c$ is the fractional rate constant at which the fraction $b$ will degrade per h. The effective rumen degradability of DM (ERD) and CP (ERDP) were calculated as $a+\left\{b \times\left[c /\left(c+k_{p}\right)\right]\right\}$ (Ørskov and McDonald, 1979), where $k_{p}$ is the ruminal particulate passage rate, which was assumed to be $0.02,0.04,0.06$ and 0.08 per $\mathrm{h}$ for feeding at maintenance, two, three and four times of the maintenance level, respectively.

\section{Gas production}

The in vitro gas accumulation was measured according to the procedures described by Weimer et al. (2005). Dried samples $(200 \mathrm{mg})$ ground with $1 \mathrm{~mm}$ sieve, were put into vials in triplicate. Three vials were placed as blank (containing $30 \mathrm{ml}$ of rumen fluid and artificial saliva mixture and no sample) in the beginning, middle and end of vial rows. Micro-mineral solution (13.2 $\mathrm{g} \mathrm{CaCl}_{2} \cdot 2 \mathrm{H}_{2} \mathrm{O}, 10 \mathrm{~g} \mathrm{MnCl} 2 \cdot 4 \mathrm{H}_{2} \mathrm{O}, 1 \mathrm{~g}$ $\mathrm{CoCl}_{2} \cdot 6 \mathrm{H}_{2} \mathrm{O}, 8 \mathrm{~g} \mathrm{FeCl}_{3} \cdot 6 \mathrm{H}_{2} \mathrm{O}$ per $100 \mathrm{ml}$ solution), rumen buffer solution $\left(4 \mathrm{~g} \mathrm{NH}_{4} \mathrm{HCO}_{3}, 35 \mathrm{~g} \mathrm{NaHCO}_{3}\right.$ per 1 liter of solution), macro mineral solution $(5.7 \mathrm{~g}$
$\mathrm{Na}_{2} \mathrm{HPO}_{4}, 6.2 \mathrm{~g} \mathrm{KH}_{2} \mathrm{PO}_{4}, 0.6 \mathrm{~g} \mathrm{MgSO}_{4} .7 \mathrm{H}_{2} \mathrm{O}$ per 1 liter of solution), resazurine solution ( $1 \mathrm{~g}$ per 1 liter) and regenerative solution $(4 \mathrm{ml} \mathrm{NaOH} 1 \mathrm{~N}, 625 \mathrm{mg}$ $\mathrm{Na}_{2} \mathrm{~S}_{9} 9 \mathrm{H}_{2} \mathrm{O}$ and $95 \mathrm{ml}$ distilled water) were prepared. The rumen fluid collected and filtered from three ruminally fistulated non-lactating Holstein cows which were used for estimating in situ ruminal degradability. All procedures of handling rumen fluid were conducted under continuous flow of $\mathrm{CO}_{2}$. The vials were then filled with $10 \mathrm{ml}$ of rumen fluid plus $20 \mathrm{ml}$ of buffer solution, and placed in a shaking water bath at $39.0 \pm 0.5^{\circ} \mathrm{C}$. Rubber stopper under $\mathrm{CO}_{2}$ gassing were sealed with a light coating of petrolatum and vials were capped with butyl rubber stoppers and sealed with aluminum crimps. Gas pressure was measured with a digital pressure gauge (UniMano 1000, NeTech, USA). Gas production was recorded at 2, 4, 6, 8, 12, 24, 36, 48,72 and $96 \mathrm{~h}$ of incubation. The disposable needles used to measure the gas production (GP) were replaced after every ten rubber stopper penetrations. The amount of GP was corrected for blanks and fitted to the following model (Ørskov and McDonald, 1979): Y=B $\left(1-\mathrm{e}^{-\mathrm{Ct}}\right)$ where, $\mathrm{B}$ is the asymptotic gas production (GP) from the digestible fraction as $\mathrm{ml}, \mathrm{C}$ is the GP rate constant for the digestible fraction per $\mathrm{h}, \mathrm{t}$ is incubation time as $\mathrm{h}$ and $\mathrm{Y}$ is GP at time t.

Metabolisable energy (ME) of samples was estimated from GP at $24 \mathrm{~h}$ as described by Close and Menke (1986):

$\mathrm{ME}(\mathrm{MJ} / \mathrm{kg} \mathrm{DM})=1.06+0.157 \times \mathrm{GP}_{24}+0.0084 \times \mathrm{CP}+$ $0.022 \times \mathrm{EE}+0.0081 \times \mathrm{CA} \quad, t \leq L \quad P=a$

Where, $\mathrm{GP}_{24}$ is gas production as $\mathrm{ml} / 200 \mathrm{mg} \mathrm{DM}$ at $24 \mathrm{~h}$ of incubation, $\mathrm{CP}$ is crude protein as $\mathrm{g} / \mathrm{kg} \mathrm{DM}$, EE is ether extract as $\mathrm{g} / \mathrm{kg} \mathrm{DM}$ and CA is crude ash as $\mathrm{g} / \mathrm{kg}$ DM.

Organic matter digestibility (OMD) was estimated as described by Menke et al. (1979):

OMD $(\mathrm{g} / \mathrm{kg} \mathrm{DM})=148.8+8.89 \times \mathrm{GP}_{24}+0.45 \times \mathrm{CP}+$ $0.0651 \times \mathrm{CA}$

Also net energy for lactation $\left(\mathrm{NE}_{1}\right)$ was calculated using equation of Menke and Steingass (1988) as follows:

$\mathrm{NE}_{1}(\mathrm{MJ} / \mathrm{kg} \mathrm{DM})=0.54+0.0959 \times \mathrm{GP}_{24}+0.0038 \times \mathrm{CP}+$ $0.001733 \times \mathrm{EE}$

\section{Statistical Analysis}

Data were analyzed using the general linear model (GLM) procedure of the SAS software (2003) using the following model:

$$
Y_{i j}=\mu+T_{i}+e_{i j}
$$

Where $\mu$ is the overall mean for each parameter, $T_{i}$ is treatment effect $(i=1-7)$ and $e_{i j}$ is the residual. Percentage data were transformed into Arcsine before analysis. The Tukey's test was used for mean 
comparisons. The effects of urea, molasses and urea plus molasses were assessed using orthogonal comparisons.

\section{Results}

\section{Fresh forages}

Chemical composition of fresh maize, sweet sorghum forages and sweet sorghum bagasse are presented in Table 1. Maize had lower DM and water soluble carbohydrates (WSC) concentrations compared with sorghum or sorghum bagasse $(\mathrm{P}<0.01)$. On the other hand, $\mathrm{CP}$, neutral detergent fibre (NDF) and neutral detergent insoluble protein were greater in fresh maize forage than other two fresh forages $(\mathrm{P}<0.01)$. Fresh sorghum and its bagasse were significantly different in DM, CP, NDF, acid detergent fibre (ADF), neutral detergent insoluble protein and acid detergent insoluble protein concentrations (Table 1).

The $\mathrm{GP}_{24}$ for maize forage was higher $(\mathrm{P}<0.05)$ than sorghum but not significantly different from sorghum bagasse (Table 2). However, $\mathrm{ME}, \mathrm{NE}_{1}$ and OMD were significantly greater $(\mathrm{P}<0.01)$ for fresh maize forage compared with sorghum forage and sorghum bagasse.

Maize forage had lower $(\mathrm{P}<0.01)$ in situ a fraction of DM compared with sweet sorghum and sorghum bagasse (Table 3). However, maize forage had greater $(\mathrm{P}<0.01) a$ fraction of $\mathrm{CP}$ than sorghum forage and sorghum bagasse. Maize forage had greater $(\mathrm{P}<0.01)$ in situ $b$ fraction of DM compared with sorghum forage and sorghum bagasse, while maize and sorghum had greater $(\mathrm{P}<0.05) b$ fraction of $\mathrm{CP}$ compared with sorghum bagasse. Degradation rate $(c)$ of $\mathrm{DM}$ or $\mathrm{CP}$ in maize forage were greater $(\mathrm{P}<0.05)$ than bagasse, while there was no difference between $c$ of maize and sorghum forage (Tables 3). The ERD for maize forage, with all rumen $k_{p}$, was higher $(\mathrm{P}<0.01)$ compared with other forages. The ERDP at all $k_{p}$ values, were highest for maize forage and lowest $(\mathrm{P}<0.01)$ for sorghum bagasse (Table 3 ).

\section{Silages}

The MS silage had the highest $(\mathrm{P}<0.05)$ and SSUM had the lowest $b$ fraction of DM (Table 4). Maximum and minimum of $b$ for DM were observed in MS and SSUM (537 and $428 \mathrm{~g} / \mathrm{kg} \mathrm{DM}$, respectively; $\mathrm{P}<0.01$ ), respectively. Chemical composition of experimental silages has been presented in the earlier report (Zafari Naeini et al., 2014). The $a$ fraction of CP for SSU, BSU and BSUM silages was greater $(\mathrm{P}<0.01)$ than that for MS (Table 5). Maximum and minimum $b$ of $\mathrm{CP}$ were observed for BS and SSU (411 and $247 \mathrm{~g} / \mathrm{kg} \mathrm{CP}$, respectively; $\mathrm{P}<0.01)$. At 0.02 and 0.04 ruminal $k_{p}$, ERDP was the greatest $(\mathrm{P}<0.01)$ for $\mathrm{MS}, \mathrm{BSU}$ and BSUM (Table 5). Silages containing urea were greater in $a$ of DM ( $<<0.05$; Table 4), $a$ of CP, and ERDP (for all $k_{p}$ values $)(\mathrm{P}<0.01$; Table 5) compared with silages without urea. Adding either urea or molasses increased $a$ fraction of both $\mathrm{DM}$ and $\mathrm{CP}$ while adding urea decreased $(\mathrm{P}<0.05)$ only $b$ fraction of $\mathrm{CP}$ (Table 4, Table 5). Adding either urea or molasses had no significant effect $(\mathrm{P}>0.05)$ on gas production parameters such as $\mathrm{ME}, \mathrm{NE}_{1}$ and $\mathrm{OMD}$ (Table 6). Silages containing urea plus molasses were greater in $\mathrm{C}$ of gas production, ME and OMD, especially for bagasse silage.

Table 1: Chemical composition (g/kg DM) of fresh whole plant maize, whole plant sweet sorghum and sweet sorghum bagasse

\begin{tabular}{lccccc}
\hline Parameter $^{1}$ & Maize & Sorghum & Bagasse & \multicolumn{3}{c}{ SEM $^{2}$} & P value $^{3}$ \\
\hline $\begin{array}{l}\text { DM (g/kg fresh } \\
\text { material) }\end{array}$ & $177^{\mathrm{c}}$ & $331^{\mathrm{b}}$ & $362^{\mathrm{a}}$ & 2.2 & $* *$ \\
$\mathrm{CP}$ & $88^{\mathrm{a}}$ & $56^{\mathrm{b}}$ & $51^{\mathrm{c}}$ & 2.4 & $* *$ \\
$\mathrm{WSC}$ & $94^{\mathrm{b}}$ & $136^{\mathrm{a}}$ & $152^{\mathrm{a}}$ & 8.8 & $* *$ \\
$\mathrm{NDF}$ & $526^{\mathrm{a}}$ & $447^{\mathrm{c}}$ & $491^{\mathrm{b}}$ & 6.1 & $* *$ \\
$\mathrm{ADF}$ & $263^{\mathrm{a}}$ & $213^{\mathrm{b}}$ & $258^{\mathrm{a}}$ & 4.1 & $* *$ \\
$\mathrm{ADL}$ & 81 & 82 & 97 & 4.7 & $\mathrm{~ns}$ \\
$\mathrm{NDIP}$ & $27^{\mathrm{a}}$ & $24^{\mathrm{b}}$ & $22^{\mathrm{c}}$ & 0.8 & $* *$ \\
ADIP & $11^{\mathrm{b}}$ & $13^{\mathrm{a}}$ & $10^{\mathrm{c}}$ & 0.3 & $* *$
\end{tabular}

${ }^{1} \mathrm{DM}$, dry matter; CP, crude protein; WSC, water soluble carbohydrates; NDF, neutral detergent fibre; ADF, acid detergent fibre; ADL, acid detergent lignin; NDIP, neutraldetergent insoluble protein, ADIP, acid-detergent insoluble protein; ${ }^{2}$ Standard error of means, $n=3 ;{ }^{3 * *}$ Significant at $\mathrm{P}<0.01$; ${ }^{\mathrm{ns}}$ non-significant; ${ }^{\mathrm{a}-\mathrm{c}}$ Within each row, means with the same superscript(s) are not significantly different.

Table 2: The gas production parameters of the fresh whole plant maize, whole plant sweet sorghum and sweet sorghum bagasse

\begin{tabular}{llllll}
\hline Parameter $^{1}$ & Maize & Sorghum & Bagasse & SEM $^{2}$ & P value $^{3}$ \\
\hline $\mathrm{GP}_{24}$ & $41.0^{\mathrm{a}}$ & $36.8^{\mathrm{b}}$ & $38.4^{\mathrm{ab}}$ & 0.68 & $*$ \\
$\mathrm{~B}$ & 68.1 & 64.4 & 65.6 & 1.16 & $\mathrm{~ns}$ \\
$\mathrm{C}$ & 0.041 & 0.037 & 0.039 & 0.002 & $\mathrm{~ns}$ \\
$\mathrm{ME}$ & $9.7^{\mathrm{a}}$ & $8.4^{\mathrm{b}}$ & $8.6^{\mathrm{b}}$ & 0.12 & $* *$ \\
$\mathrm{NE}_{1}$ & $4.9^{\mathrm{a}}$ & $4.3^{\mathrm{b}}$ & $4.5^{\mathrm{b}}$ & 0.07 & $* *$ \\
$\mathrm{OMD}$ & $557^{\mathrm{a}}$ & $505^{\mathrm{b}}$ & $517^{\mathrm{b}}$ & 6.1 & $* *$ \\
\hline
\end{tabular}

${ }^{1} \mathrm{GP}_{24}$, gas production (ml/g DM) at 24 hour incubation; $\mathrm{B}$, GP from the digestible fraction (ml); C, GP rate constant for the insoluble fraction; ME, metabolisable energy $(\mathrm{MJ} / \mathrm{kg}$ $\mathrm{DM}) ; \mathrm{NE}_{\mathrm{l}}$, net energy (MJ/kg DM); OMD, organic matter digestibility $(\mathrm{g} / \mathrm{kg} \mathrm{DM}) .{ }^{3 *}$ Significant at $\mathrm{P}<0.05,{ }^{*}$ Significant at $\mathrm{P}<0.01,{ }^{n s}$ non-significant. ${ }^{2}$ Standard error of means, $\mathrm{n}=3$; $^{\text {a }}$

${ }^{-c}$ Within each row, means with the same superscript(s) are not significantly different.

\section{Discussion}

The low DM concentration of whole plant maize (177 g/kg Fresh material; Table 1) was due to the early stage of harvesting which accordingly resulted in low DM concentration of MS (203 g/kg Fresh material) after 90 days of ensiling ( Zafari Naeini et al., 2014). In the current study, silages had good visual appearance, 
odour and colour, low final $\mathrm{pH}$ (i.e. 3.74-3.91), which in addition to absence of butyric acid production, indicate good fermentation quality (McDonald et al., 1991). Adding $10 \mathrm{~g} / \mathrm{kg} \mathrm{DM}$ urea to the silages had no effect on NDF and ADF concentrations but there are reports showing that addition of 45 to $65 \mathrm{~g} / \mathrm{kg}$ urea to low quality grass forages or plant wastes (such as bagasse in this study) decreased NDF concentration; an effect which was more evident for lower quality forages (high NDF concentration) than for high quality forages (low NDF concentration; Ramirez et al., 2007).

However, it is possible that decrease in fibre concentrations results simply from the addition of high amounts of urea to the silages. Some researchers (Mattoni et al., 2007; Larwence, 2000) have reported that urea supplementation increased DM and NDF contents in sorghum straw compared with the untreated straw. Silages with additives were lower than those without additives in hemicellulose and cellulose contents, and also $b$ fraction of in situ rumen degradability for both DM and CP.

The OMD and ME were not improved due to the addition of molasses, which are in agreement with results of Guney et al. (2007) in sorghum silage. Celik et al. (2009) reported that urea, molasses and urea plus molasses had no significant effect on mean $\mathrm{pH}$ and ME value of maize silage, but had significant effect on in vitro OMD. This study showed that adding urea plus molasses had significant effect on $\mathrm{pH}, \mathrm{ME}$ and $\mathrm{OMD}$ values of sweet sorghum silage.

In this study, no significant difference of $\mathrm{ME}$ content between untreated and urea-treated sorghum silages was observed. In contrast, Guney et al. (2007) reported that the addition of different levels of urea decreased the OMD and ME values in sorghum silage. Adding mixture of urea and molasses to bagasse silages increased OMD, while for sorghum silage the additives were not effective. Some studies reported that molasses as additive increased the ME value of silages (Seoane et al., 1992; Petit and Veira, 1994), which is contrary to the current study. For conventional feeds, there is a positive correlation between the calculated $\mathrm{ME}$ in vitro gas production (using fat and protein concentrations) with the ME obtained in vivo (Menke and Steingass, 1988; Sallam et al., 2007). Adding urea or molasses alone had no effect on $\mathrm{GP}_{24}, \mathrm{~B}$ and $\mathrm{NE}_{1}$, while adding mixture of urea and molasses to sorghum and bagasse silage increased $\mathrm{C}, \mathrm{ME}$ and $\mathrm{OMD}$.

Table 3: DM and CP in situ degradability of the fresh maize, sorghum and sorghum bagasse

\begin{tabular}{|c|c|c|c|c|c|c|c|c|c|c|}
\hline \multirow[b]{2}{*}{ Parameter $^{1}$} & \multicolumn{4}{|c|}{ DM in situ degradability } & \multicolumn{6}{|c|}{$\mathrm{CP}$ in situ degradability } \\
\hline & Maize & Sorghum & Bagasse & SEM $^{2}$ & $\mathrm{P}_{\text {value }}^{3}$ & Maize & Sorghum & Bagasse & SEM & $\mathrm{P}$ value \\
\hline$a$ & $220^{b}$ & $256^{\mathrm{a}}$ & $254^{\mathrm{a}}$ & 4.2 & *** & $281^{\mathrm{a}}$ & $184^{b}$ & $165^{b}$ & 9.5 & $* *$ \\
\hline$b$ & $549^{\mathrm{a}}$ & $465^{\mathrm{b}}$ & $470^{\mathrm{b}}$ & 6.6 & $* *$ & $507^{\mathrm{a}}$ & $504^{\mathrm{a}}$ & $466^{\mathrm{b}}$ & 11.4 & * \\
\hline$c$ & $0.132^{\mathrm{a}}$ & $0.123^{\mathrm{a}}$ & $0.106^{\mathrm{b}}$ & 0.0031 & $* *$ & $0.150^{\mathrm{a}}$ & $0.133^{\mathrm{ab}}$ & $0.120^{\mathrm{b}}$ & 0.0079 & $*$ \\
\hline \multicolumn{6}{|c|}{ ERD } & \multicolumn{5}{|c|}{ ERDP } \\
\hline$k_{p}=0.02$ & $697^{\mathrm{a}}$ & $656^{\mathrm{b}}$ & $650^{b}$ & 3.5 & $* *$ & $728^{\mathrm{a}}$ & $622^{b}$ & $564^{\mathrm{c}}$ & 5.1 & $* *$ \\
\hline$k_{p}=0.04$ & $642^{\mathrm{a}}$ & $608^{\mathrm{b}}$ & $595^{\mathrm{b}}$ & 3.3 & $* *$ & $681^{\mathrm{a}}$ & $571^{\mathrm{b}}$ & $514^{\mathrm{c}}$ & 6.3 & $* *$ \\
\hline$k_{p}=0.06$ & $598^{\mathrm{a}}$ & $569^{\mathrm{b}}$ & $554^{\mathrm{c}}$ & 3.2 & $* *$ & $643^{\mathrm{a}}$ & $531^{\mathrm{b}}$ & $475^{\mathrm{c}}$ & 7.2 & $* *$ \\
\hline$k_{p}=0.08$ & $562^{\mathrm{a}}$ & $539^{\mathrm{b}}$ & $522^{\mathrm{c}}$ & 3.2 & $* *$ & $611^{\mathrm{a}}$ & $499^{b}$ & $444^{\mathrm{c}}$ & 7.6 & $* *$ \\
\hline
\end{tabular}

$a$, immediately soluble fraction $(\mathrm{g} / \mathrm{kg}) ; b$, slowly degradable fraction $(\mathrm{g} / \mathrm{kg}) ; c$, fractional rate constant at which the fraction $b$ is degraded (/h); ERD, effective rumen degradability of DM; ERDP, effective rumen degradability of CP; $k_{p}$, constant ruminal passage rate $(/ \mathrm{h}) ;{ }^{2}$ Standard error of means, $\mathrm{n}=3 ;{ }^{3 *}$ Significant at $\mathrm{P}<0.05,{ }^{* *}$ Significant at $\mathrm{P}<0.01$; ${ }^{\mathrm{a}-\mathrm{c}}$ Within each row, means with the same superscript(s) are not significantly different.

Table 4: DM in situ degradability of maize, sorghum and sorghum bagasse silages with or without urea and molasses after 90 days ensiling

\begin{tabular}{|c|c|c|c|c|c|c|c|c|c|c|c|}
\hline \multirow{2}{*}{ Parameter $^{1}$} & \multicolumn{7}{|c|}{ Silage $^{2}$} & \multirow[b]{2}{*}{ SEM $^{3}$} & \multicolumn{3}{|c|}{ Orthogonal comparisons ${ }^{4}$} \\
\hline & MS & SS & SSU & SSUM & BS & BSU & BSUM & & $\mathrm{U}$ & $\mathrm{M}$ & $\mathrm{U}+\mathrm{M}$ \\
\hline$a$ & $251^{\mathrm{d}}$ & $271^{\mathrm{cd}}$ & $284^{\text {bc }}$ & $314^{\mathrm{a}}$ & $251^{\mathrm{d}}$ & $266^{\mathrm{cd}}$ & $304^{\mathrm{ab}}$ & 5.3 & $*$ & $* *$ & $* *$ \\
\hline$b$ & $537^{\mathrm{a}}$ & $456^{\mathrm{b}}$ & $455^{\mathrm{b}}$ & $428^{\mathrm{c}}$ & $462^{\mathrm{b}}$ & $455^{\mathrm{b}}$ & $453^{\mathrm{b}}$ & 4.4 & $\mathrm{~ns}$ & $* *$ & $* *$ \\
\hline$c$ & 0.160 & 0.111 & 0.106 & 0.127 & 0.108 & 0.104 & 0.107 & 0.0274 & ns & $*$ & Ns \\
\hline \multicolumn{12}{|l|}{ ERD } \\
\hline$k_{p}=0.02$ & $702^{\mathrm{a}}$ & $658^{\mathrm{bc}}$ & $667^{\mathrm{bc}}$ & $683^{\mathrm{ab}}$ & $640^{c}$ & $647^{\mathrm{c}}$ & $686^{\mathrm{ab}}$ & 6.6 & ns & $* *$ & $* *$ \\
\hline$k_{p}=0.04$ & $642^{\mathrm{a}}$ & $607^{\mathrm{abc}}$ & $614^{\mathrm{abc}}$ & $639^{\mathrm{ab}}$ & $587^{\mathrm{c}}$ & $594^{\mathrm{bc}}$ & $634^{\mathrm{ab}}$ & 9.5 & ns & $* *$ & $* *$ \\
\hline$k_{p}=0.06$ & $597^{\mathrm{ab}}$ & $567^{\mathrm{ab}}$ & $575^{\mathrm{ab}}$ & $604^{\mathrm{a}}$ & $547^{\mathrm{b}}$ & $554^{\mathrm{ab}}$ & $595^{\mathrm{ab}}$ & 11.5 & $\mathrm{~ns}$ & $* *$ & $* *$ \\
\hline$k_{p}=0.08$ & 563 & 536 & 544 & 576 & 515 & 523 & 564 & 12.9 & $\mathrm{~ns}$ & $* *$ & $* *$ \\
\hline
\end{tabular}

${ }^{1} a$, immediately soluble fraction $(\mathrm{g} / \mathrm{kg}) ; b$, slowly degradable fraction $(\mathrm{g} / \mathrm{kg}) ; c$, fractional rate constant at which the fraction $b$ is degraded (/h); ERD, effective rumen degradability of DM; $k_{p}$, constant ruminal passage rate $(/ \mathrm{h}) ;{ }^{2}$ MS, maize silage; SS, sweet sorghum silage; BS, sweet sorghum bagasse silage; suffixes of U and M refer to urea and molasses, respectively; ${ }^{3}$ Standard error of means, $\mathrm{n}=3 ;{ }^{4} \mathrm{U}$, orthogonal comparison of SSU and BSU vs. SS and BS i.e. effect of urea; U, orthogonal comparison of SSUM and BSUM vs. SSU and BSU i.e. effect of molasses; U + M, orthogonal comparison of SSUM and BSUM vs. SS and BS i.e. effect of urea plus molasses; ${ }^{*}, \mathrm{P}<0.05$; ${ }^{*}, \mathrm{P}<0.01$; ns, non-significant $(\mathrm{P}>0.05)$; ${ }^{\mathrm{a}-\mathrm{d}}$ Within each row, means with the same superscript(s) are not significantly different. 
Res. Opin. Anim. Vet. Sci., 2016, 6(8): 248-255.

Table 5: In situ CP degradability of maize, sorghum and sorghum bagasse silages with or without urea and molasses after 90 days ensiling

\begin{tabular}{|c|c|c|c|c|c|c|c|c|c|c|c|}
\hline \multirow{2}{*}{ Parameter $^{1}$} & \multicolumn{7}{|c|}{ Silage $^{2}$} & \multirow[b]{2}{*}{ SEM $^{3}$} & \multicolumn{3}{|c|}{ Orthogonal comparisons ${ }^{4}$} \\
\hline & MS & $\mathrm{SS}$ & SSU & SSUM & $\mathrm{BS}$ & $\mathrm{BSU}$ & BSUM & & $\mathrm{U}$ & $\mathrm{M}$ & $\mathrm{U}+\mathrm{M}$ \\
\hline$a$ & $424^{b}$ & $316^{\mathrm{c}}$ & $488^{\mathrm{a}}$ & $408^{\mathrm{b}}$ & $225^{\mathrm{d}}$ & $496^{\mathrm{a}}$ & $490^{\mathrm{a}}$ & 9.7 & $* *$ & $* *$ & $* *$ \\
\hline$b$ & $359^{\mathrm{b}}$ & $360^{\mathrm{b}}$ & $247^{\mathrm{e}}$ & $338^{\mathrm{bc}}$ & $411^{\mathrm{a}}$ & $304^{\text {cd }}$ & $296^{\mathrm{d}}$ & 8.8 & $* *$ & $* *$ & $* *$ \\
\hline$c$ & $0.161^{\mathrm{ab}}$ & $0.136^{\mathrm{bc}}$ & $0.148^{\mathrm{b}}$ & $0.195^{\mathrm{a}}$ & $0.168^{\mathrm{ab}}$ & $0.100^{\mathrm{c}}$ & $0.135^{\mathrm{bc}}$ & 0.0096 & ns & $* *$ & Ns \\
\hline \multicolumn{12}{|l|}{ ERDP } \\
\hline$k_{p}=0.02$ & $743^{\mathrm{a}}$ & $628^{c}$ & $706^{\mathrm{b}}$ & $714^{\mathrm{b}}$ & $592^{\mathrm{d}}$ & $747^{\mathrm{a}}$ & $748^{\mathrm{a}}$ & 4.0 & $* *$ & ns & $* *$ \\
\hline$k_{p}=0.04$ & $711^{\mathrm{a}}$ & $592^{\mathrm{c}}$ & $682^{\mathrm{b}}$ & $688^{\mathrm{b}}$ & $556^{\mathrm{d}}$ & $710^{\mathrm{a}}$ & $718^{\mathrm{a}}$ & 4.6 & $* *$ & ns & $* *$ \\
\hline$k_{p}=0.06$ & $685^{\mathrm{ab}}$ & $564^{\mathrm{c}}$ & $664^{\mathrm{b}}$ & $666^{\mathrm{b}}$ & $527^{\mathrm{d}}$ & $683^{\mathrm{ab}}$ & $695^{\mathrm{a}}$ & 5.2 & $* *$ & ns & $* *$ \\
\hline$k_{p}=0.08$ & $664^{\mathrm{ab}}$ & $544^{\mathrm{c}}$ & $648^{\mathrm{b}}$ & $647^{\mathrm{b}}$ & $503^{\mathrm{d}}$ & $676^{\mathrm{ab}}$ & $677^{\mathrm{a}}$ & 5.6 & $* *$ & ns & $* *$ \\
\hline
\end{tabular}

${ }^{1} a$, immediately soluble fraction $(\mathrm{g} / \mathrm{kg}) ; b$, slowly degradable fraction $(\mathrm{g} / \mathrm{kg}) ; c$, fractional rate constant at which the fraction $b$ is degraded (/h); ERDP, effective rumen degradability of CP; $k_{p}$, constant ruminal passage rate $(/ \mathrm{h}) ;{ }^{2} \mathrm{MS}$, maize silage; SS, sweet sorghum silage; BS, sweet sorghum bagasse silage; suffixes of U and M refer to urea and molasses, respectively; ${ }^{3}$ Standard error of means, $\mathrm{n}=3 ;{ }^{4} \mathrm{U}$, orthogonal comparison of SSU and BSU vs. SS and BS i.e. effect of urea; U, orthogonal comparison of SSUM and BSUM vs. SSU and BSU i.e. effect of molasses; U + M, orthogonal comparison of SSUM and BSUM vs. SS and BS i.e. effect of urea plus molasses; *, $\mathrm{P}<0.05$; **, $\mathrm{P}<0.01$; ns, non-significant $(\mathrm{P}>0.05)$; ${ }^{\mathrm{a}-\mathrm{e}}$ Within each row, means with the same superscript (s) are not significantly different.

Table 6: Gas production parameters of maize, sorghum and sorghum bagasse silages with or without urea and molasses after 90 days ensiling

\begin{tabular}{|c|c|c|c|c|c|c|c|c|c|c|c|}
\hline \multirow{2}{*}{ Parameter $^{1}$} & \multicolumn{7}{|c|}{ Silages $^{2}$} & & \multicolumn{3}{|c|}{ Orthogonal contrasts } \\
\hline & MS & SS & SSU & SSUM & $\mathrm{BS}$ & BSU & BSUM & SEM $^{3}$ & $\mathrm{U}$ & $\mathrm{M}$ & $\mathrm{U}+\mathrm{M}$ \\
\hline $\mathrm{GP}_{24}$ & 41.6 & 36.2 & 35.9 & 36.8 & 32.0 & 36.6 & 38.7 & 1.63 & $\overline{\mathrm{ns}}$ & $\mathrm{ns}$ & Ns \\
\hline $\mathrm{B}^{2+}$ & 75.4 & 67.1 & 61.2 & 63.8 & 61.5 & 65.2 & 63.9 & 1.89 & ns & ns & Ns \\
\hline $\mathrm{C}$ & 0.030 & 0.032 & 0.037 & 0.044 & 0.031 & 0.033 & 0.041 & 0.0035 & ns & ns & * \\
\hline ME & $9.6^{\mathrm{a}}$ & $8.2^{\mathrm{ab}}$ & $8.4^{\mathrm{ab}}$ & $8.5^{\mathrm{ab}}$ & $7.5^{\mathrm{b}}$ & $8.5^{\mathrm{ab}}$ & $8.9^{\mathrm{ab}}$ & 0.30 & ns & ns & $*$ \\
\hline $\mathrm{NE}_{1}$ & $4.9^{\mathrm{a}}$ & $4.3^{\mathrm{ab}}$ & $4.3^{\mathrm{a}}$ & $4.4^{\mathrm{ab}}$ & $3.8^{\mathrm{b}}$ & $4.4^{\mathrm{ab}}$ & $4.6^{\mathrm{a}}$ & 0.16 & ns & ns & Ns \\
\hline OMD & $561^{\mathrm{a}}$ & $499^{\mathrm{ab}}$ & $505^{\mathrm{ab}}$ & $511^{\mathrm{ab}}$ & $456^{\mathrm{b}}$ & $511^{\mathrm{ab}}$ & $531^{\mathrm{a}}$ & 14.6 & ns & $\mathrm{ns}$ & * \\
\hline
\end{tabular}

${ }^{1} \mathrm{GP}_{24}$, gas production $(\mathrm{ml} / \mathrm{g} \mathrm{DM})$ at $24 \mathrm{~h}$ of incubation; B, GP from the digestible fraction (ml); C, GP rate constant for the insoluble fraction; $\mathrm{ME}$, metabolisable energy $(\mathrm{MJ} / \mathrm{kg} \mathrm{DM}) ; \mathrm{NE}_{\mathrm{l}}$, net energy $(\mathrm{MJ} / \mathrm{kg} \mathrm{DM})$; OMD, organic matter digestibility $(\mathrm{g} / \mathrm{kg} \mathrm{DM}) ;{ }^{2} \mathrm{MS}$, maize silage; SS, sweet sorghum silage; BS, sweet sorghum bagasse silage; suffixes of U and M refer to urea and molasses, respectively; ${ }^{3}$ Standard error of means, $\mathrm{n}=3 ;{ }^{4} \mathrm{U}$, orthogonal comparison of SSU and BSU vs. SS and BS i.e. effect of urea; U, orthogonal comparison of SSUM and BSUM vs. SSU and BSU i.e. effect of molasses; U + M, orthogonal comparison of SSUM and BSUM vs. SS and BS i.e. effect of urea plus molasses; *, $\mathrm{P}<0.05$; **, $\mathrm{P}<0.01$; ns, non-significant $(\mathrm{P}>0.05)$; ${ }^{\mathrm{a}-\mathrm{b}}$ Within each row, means with the same superscript(s) are not significantly different.

There was no relationship between urea or molasses supplementation of the silages with $\mathrm{GP}_{24}$. The $\mathrm{C}$ increased by the addition of urea or urea plus molasses, but this increase was only significant when mixture of urea and molasses were used. Larbi et al. (1998) and Nsahlai et al. (1994) reported positive correlation between protein concentration and rate of gas production, and negative correlation between concentrations of NDF and ADF, with the rate and extent of gas production. Mahala and Khalifa (2007) reported that adding molasses to sorghum silage decreased NDF and ADF concentrations, and increased gas production rate, $\mathrm{OMD}$ and $\mathrm{ME}$ compared with the control treatment, which may be due to lower ADF and NDF content of molasses. This finding was not in agreement with the finding of Nayigihugu et al. (1995) who observed that adding molasses lowered $\mathrm{pH}$, NDF and ADF concentrations and increased in vitro dry matter digestibility of Bermuda grass silage.

Higher in situ a fraction of DM degradability for fresh sorghum forage and bagasse compared with maize can be a result of high WSC concentration. The addition of urea to SS and BS increased $a$ fraction of $\mathrm{CP}$, while the addition of molasses to SSU reduced this fraction. Urea and molasses both are soluble in the rumen and using them as additives is expected to change $a$ fraction of in situ degradability. Di Marcoa et al. (2009) reported a close relationship between in situ DM disappearance and in vivo DM digestibility at $12 \mathrm{~h}$ of incubation for sweet sorghum silages.

\section{Conclusions}

The present experiment based on laboratory silos showed that sweet sorghum bagasse can be ensiled successfully with or without urea and molasses as silage additives. However, simultaneous addition of urea and molasses would improve the metabolisable energy content, organic matter digestibility and in situ rumen degradability of dry matter and crude protein of whole plant sweet sorghum and sweet sorghum bagasse silages, although molasses seems not to be beneficial for whole sweet sorghum silage compared with its 
bagasse. It seems that urea as an additive is necessary for sweet sorghum bagasse silages to increase its CP content and its quality for long time preservation.

\section{References}

AFRC (1992) Nutritive requirements of ruminant animals: Protein Nutrition Abstract Review (Ser. B) 62: 787-835.

Almodares A, Hadi MR, Ahmadpour H (2008) Sorghum stem yield and soluble carbohydrates under phonological stages and salinity levels. African J Biotechnol 7:4051-4055.

Almodares A, Sepahi A (1996) Comparison among sweet sorghum cultivars, lines and hybrids for sugar production. Annual Plant Physiol 10:50-55.

Amer S, Seguin P, Mustafa AF (2012) Short communication: Effects of feeding sweet sorghum silage on milk production of lactating dairy cows. J Dairy Sci 95:859-863.

Bolsen KK, Moore KJ, Coblentz WK, Siefers MK, White JS (2003) Sorghum silage. In: L. Al-Amoodi (Editor), Silage Science and Technology. ASACSSA-SSSA, Madison, WI, USA, pp. 609-632.

Cabral Filho SLS, Abdalla AL, Bueno ICS, Nozella EF, Rodrigues JAS (2005) Ruminal fermentation and degradability of sorghum cultivar whole crop, and grains, using an in vitro gas production. Anim Feed Sci Technol 123:329-339.

Celik S, Budag C, Demirel M, Bakici Y, Celik S (2009) The effects of adding urea and molasses to corn harvested at dough stage on silage fermentation quality, in vitro organic matter digestibility and metabolic energy contents. J Anim Vet Adv 8:1921-1924.

Close WH, Menke KH (1986) Evaluation on the basis of metabolizable energy. In: Deutsche Stiftung für Internationale Entwicklung, Zentralstelle für Ernährung und Landwirtschaft (Editors), Selected Topics in Animal Nutrition. A Manual Prepared for the 3rd Hohenheim Course on Animal Nutrition in the Tropics and Semi-Tropics, Second ed. Feldafing, Germany, pp. 60-63.

Demirel M, Deniz S, Yilmaz I, Nursoy H (2004) The effect of adding urea or urea+molasses in some sorghum varieties harvested at dough stage on silage quality and dry matter yield. Turkish $\mathrm{J}$ Vet Anim Sci 28:29-37.

Di Marcoa ON, Ressia MA, Arias S, Aello MS, Arzadún M (2009) Digestibility of forage silages from grain, sweet and bmr sorghum types: Comparison of in vivo, in situ and in vitro data. Anim Feed Sci Technol 153:161-168.

FAO (2013) Accessed Nov, 2013. Available at < http://faostat.fao.org/site/567/DesktopDefault.aspx ?PageID=567\#ancor $>$.
Filya I (2001) Silage fermantation. Ataturk Univeristy Agricultural Department Review 32:87-93.

Gowda PH, Baumhardt RL, Esparza AM, Marek TH, Howell TA (2007) Suitability of cotton as an alternative crop in the Ogallala Aquifer region. Agronomy J 99:1397-1403.

Guney M, Demirel M, Celik S, Bakici Y, Levendoglu T (2007) Effects of urea, molasses and urea plus molasses supplementation to sorghum silage on the silage quality, in vitro organic matter digestibility and metabolic energy contents. J Biological Sci 7:401-404.

Harris LE, Mitchell HH (1941) Urea in the synthesis of protein in the paunch of the ruminant. J Nutr 22: 167-196.

Larbi A, Smith JW, Kurdi IO, Adekunle IO, Raji AM, Ladipo DO (1998) Chemical composition, rumen degradation, and gas production characteristics of some multipurpose fodder trees and shrubs during wet and dry seasons in the humid tropics. Anim Feed Sci Technol 72: 81-96.

Larwence A, Triki S, Chabaca R, Rezzoug A (2000) Proposition d'une méthode subhumide de traitement des pailles à l'urée. Annual Zootechnie 49: 479-485.

Mahala AG, Khalifa IM (2007) The Effect of Molasses Levels on Quality of Sorghum (Sorghum bicolor) Silage. Res J Anim Vet Sci 2: 43-46.

Mattoni M, Schiavone A, Tarantola M, Ladetto G, De Meneghi D, Kanwe AB (2007) Effect of urea treatment on the nutritive value of local sorghum and millet straw: a comparative study on growing performance of Djallonke rams. Italian J Anim Sci 6:318-320.

McDonald P, Henderson AR, Heron SJE (1991) The biochemistry of silage. Second Edition. Chalcombe Publications, Marlow, Bucks, UK.

Menke KH, Raab L, Salewski A, Steingass H, Fritz D, Schneider W (1979) The estimation of the digestibility and metabolisable energy content of ruminant feedstuffs from the gas production when they are incubated with rumen liquor. J Agric Sci 93: 217-222.

Menke KH, Steingass H (1988) Estimation of the energetic feed value obtained from chemical analyses and gas production using rumen fluid. Anim Res Develop 28:7-55.

Nayigihugu V, Kellogg DW, Johnson ZB, Scott M, Anschutz KS (1995) Effects of adding levels of molasses on composition of bermudagrass (Cynodon dactylon) silage. J Anim Sci 73:Suppl.1, 200.

NRC (2001) Nutrient requirements of dairy cattle. Seventh revised edition, 2001. Washington, D.C., National Academy Press. 
Nsahlai IV, Siaw DEKA, Osuji PO (1994) The relationship between gas production and chemical composition of 23 browses of the genus Sesbania. J Sci Food Agric 65:13-21.

Oliver AL, Grant RJ, Pedersen JF, O'Rear J ( 2004) Comparison of brownmidrib-6 and -18 forage sorghum with conventional sorghum and corn silage in diets of lactating dairy cows. J Dairy Sci 87:637-644.

Ørskov ER, McDonald I (1979) The estimation of protein degradability in the rumen from incubation measurements weighted according to rate of passage. J Agric Sci (Cambridge) 92:499-503.

Pesce DMC, Goncalves LC, Rodrigues NM, Borges I, Rodrigues JAS ( 2000) Percentage and loss of dry matter and in vitro dry matter digestibility of 20 sorghum genotypes silages. Arquivo Brasileiro de Medicina Veterinária e Zootecnia 52:250-255.

Petit HV, Veira DM (1994) Digestion characteristic of beef steers feed silage and different levels of energy with or without protein supplementation. J Anim Sci 72:3213-3220.

Ramirez GR, Aguilera-Gonzalez JC, Garcia-Diaz G, Nunez-Gonzalez AM (2007) Effect of urea treatment on chemical composition and digestion of cenchrus ciliaris and cynodon dactylon hays and zea mays residues. J Anim Vet Advan 6:1036-1041.

Sallam SMA, Nasser MEA, El-Waziry AM, Bueno ICS, Abdalla AL (2007) Use of an in vitro rumen gas production technique to evaluate some ruminant feedstuffs. J Appl Sci Res 3:34-41.
SAS. 2003 (SAS) Statistical Analysis Systems 2003. User's Guide. SAS Institute Incorporation, Cary, NC, USA.

Seoane JR, Christen AM, Veira DM, Fontecilla J (1992) Performance of growing steers fed quackgrass hay supplemented with canola meal. Canadian J Anim Sci 72:239-247.

Sipos B, Réczey J, Somorai Z, Kádár Z, Dienes D, Réczey K ( 2009) Sweet Sorghum as Feedstock for Ethanol Production: Enzymatic hydrolysis of steam-pretreated bagasse. Appl Biochem Biotechnol 153:151-162.

Tetlow RM (1992) Whole-Crop cereals for beef cattle. pp.73-84. In: B.A. Stark, J.M. Wilkinson (Editors). Whole-crop cereals. Second Edition. Chalcombe Publication, Marlow.

Weimer PJ, Dien BS, Springer TL, Vogel KP (2005) In vitro gas production as a surrogate measure of the fermentability of cellulosic biomass to ethanol. Appl Microbiol Biotechnol 67:52-58.

Van-Oosteroma EJ, Carberryb PS, Muchow RC (2001) Critical and minimum $\mathrm{N}$ contents for development and growth of grain sorghum. Field Crops Res 70: 55-73.

Zafari Naeini S, Khorvash M, Rowghani E, Bayat AR, Nikousefat Z (2014) Effects of urea and molasses supplementation on chemical composition, protein fractionation and fermentation characteristics of sweet sorghum and bagasse silages as alternative silage crop compared with maize silage in the arid areas. Res Opin Anim Vet Sci 4: 343-352. 